\title{
Subglacial conditions at a sticky spot along Kamb Ice Stream, West Antarctica
}

\author{
L. E. Peters and S. Anandakrishnan \\ Department of Geosciences, The Pennsylvania State University, University Park, PA 16802 (lpeters@geosc.psu.edu, sak@essc.psu.edu)
}

\begin{abstract}
We present the results of a seismic reflection experiment performed transverse to flow a few tens of kilometers above the main trunk of Kamb Ice Stream, West Antarctica, where we image a basal high surrounded by variable subglacial conditions. This high rises as much as $200 \mathrm{~m}$ above the surrounding bed, acting as a major sticking point that resists fast flow. Application of the amplitude variation with offset (AVO) seismic technique has highlighted regions of frozen sediments along our profile, suggesting that the ice stream is experiencing basal freeze-on in the region. The bedrock high appears to be at least partially draped in sediment cover, with a concentrated area of weak, dilatant till flanking one edge. This dilatant till is further dispersed along our profile, though it does not possess enough continuity to maintain streaming ice conditions. These results support the hypothesis that the ongoing shutdown of Kamb Ice Stream is due to a loss in continuous basal lubrication.
\end{abstract}

Citation: Peters, L.E., and S. Anandakrishnan (2007), Subglacial conditions at a sticky spot along Kamb Ice Stream, West Antarctica, in Antarctica: A Keystone in a Changing World - Online Proceedings of the $10^{\text {th }}$ ISAES, edited by A.K. Cooper and C.R. Raymond et al., USGS Open-File Report 2007-1047, Short Research Paper 097, 5 p.; doi:10.3133/of2007-1047.srp097

\section{Introduction}

The instability of the West Antarctic Ice Sheet (WAIS) is dependent on how effectively interior ice can be drained to the ocean, as complete collapse of the ice sheet would lead to a $6 \mathrm{~m}$ rise in global sea level (Oppenheimer, 1998). The mass balance of this marine ice sheet is regulated by a series of ice streams that extend from the interior of West Antarctica to either floating ice shelves or the open ocean. These ice streams, which can flow at speeds as high as $3 \mathrm{~km} \mathrm{a}^{-1}$ (Joughin et al., 2003), have been undergoing extensive reorganizations in their flow regimes and discharge capacities (e.g., Jacobel et al., 1996; 2000; Conway et al., 2002; Bindschadler et al., 2005). The Siple Coast is of particular interest, as Kamb Ice Stream is currently stagnant along its main trunk (Retzlaff and Bentley, 1993), Whillans Ice Stream is showing signs of deceleration (Bindschadler et al., 2005; Joughin et al., 2005), and the remaining ice streams appear to be in a stable state.

The locations of the ice streams draining the WAIS are controlled by geologic conditions, as streaming ice is observed where subglacial sedimentary features are present (Anandakrishnan et al., 1998; Bell et al., 1998; Blankenship et al., 2001; Studinger et al., 2001; Peters et al., 2006). The continuity of these sedimentary basins has been linked to marine deposition up to the paleoshoreline of the Antarctic continent when it was ice-free (Scherer et al., 1998; Blankenship et al., 2001; Studinger et al., 2001). These sedimentary structures form source areas for the production of a soft, potentially deformable till layer, which serves to smooth the bed and promote basal sliding. In some locations this till has either been fully eroded, starved of basal water, or frozen to create sticky spots along the bed, increasing basal friction and causing a slowdown in the basal regime (e.g., Alley et al., 1994; Anandakrishnan and Alley, 1997; Anandakrishnan et al., 2001).

We present the results of a seismic reflection experiment performed transverse to ice flow along Kamb
Ice Stream (Figure 1), where the flow of the ice stream is in transition: upstream of this location, the ice is flowing at $\sim 40-60 \mathrm{~m} \mathrm{a}^{-1}$, with ice flow becoming stagnant in the downstream direction. We imaged subglacial structure



Figure 1. MODIS Mosaic of Antarctica image of Kamb Ice Stream along the Siple Coast of West Antarctica (Haran et al., 2005), highlighting the seismic reflection experiment presented here (black line) and the nearby CalTech boreholes (black circles) (Kamb, 2001; Engelhardt, 2004). The dashed lines outline the ice stream margins and the tear-drop-shaped sticky spot along Kamb Ice Stream. The radar studies of Catania et al. (2003), Jacobel et al. (2005), and Pettersson et al. (2006) were focused around the labeled sticky spot. The black box on the inset map gives the location of the satellite image in relation to the rest of Antarctica. 
along our seismic profile, and applied the amplitude variation with offset (AVO) seismic technique to constrain basal conditions and determine their influence on the observed flow regime. The observed local high at the bed is a sticky spot (e.g., Jacobel et al., 1993; Retzlaff and Bentley, 1993), composed of frozen sediments and possibly exposed bedrock. A dilatant till-water system is present on the edges of the subglacial high, with zones of frozen sediments roughening an otherwise soft, lubricating bed. These results are in agreement with the hypothesis that a loss of continuous lubricating till is the reason for the ongoing shutdown of fast flow along Kamb Ice Stream (Anandakrishnan et al., 2001).

\section{Data collection}

During the $2002-2003$ Antarctic field season, $10.8 \mathrm{~km}$ of multi-channel seismic reflection data were collected across Kamb Ice Stream, a few tens of kilometers upstream of its stagnant trunk (Figure 1). The seismic profile was positioned transverse to ice flow, where ice velocities average $\sim 20 \mathrm{~m} \mathrm{a}^{-1}$, to image subglacial structure and basal conditions. The seismic profile was located $\sim 30 \mathrm{~km}$ upstream of several boreholes drilled to the bed of Kamb Ice Stream, where a basal water system was observed (Kamb, 2001; Engelhardt, 2004).

The seismic data were collected with a receiver array of 120 single-component $40 \mathrm{~Hz}$ geophones at a $10 \mathrm{~m}$ spacing. The geophones were positioned vertically to record compressional waves. Explosive charges were used as our seismic source, with charges ranging from $150 \mathrm{~g}$ to $900 \mathrm{~g}$ in size, and were detonated $30 \mathrm{~m}$ and $1230 \mathrm{~m}$ from the end of the receiver spread, after which the entire source-receiver array was moved $300 \mathrm{~m}$ and the process repeated. Four-fold data were produced, effectively giving us continuous data from $30 \mathrm{~m}$ to 2420 m offset.

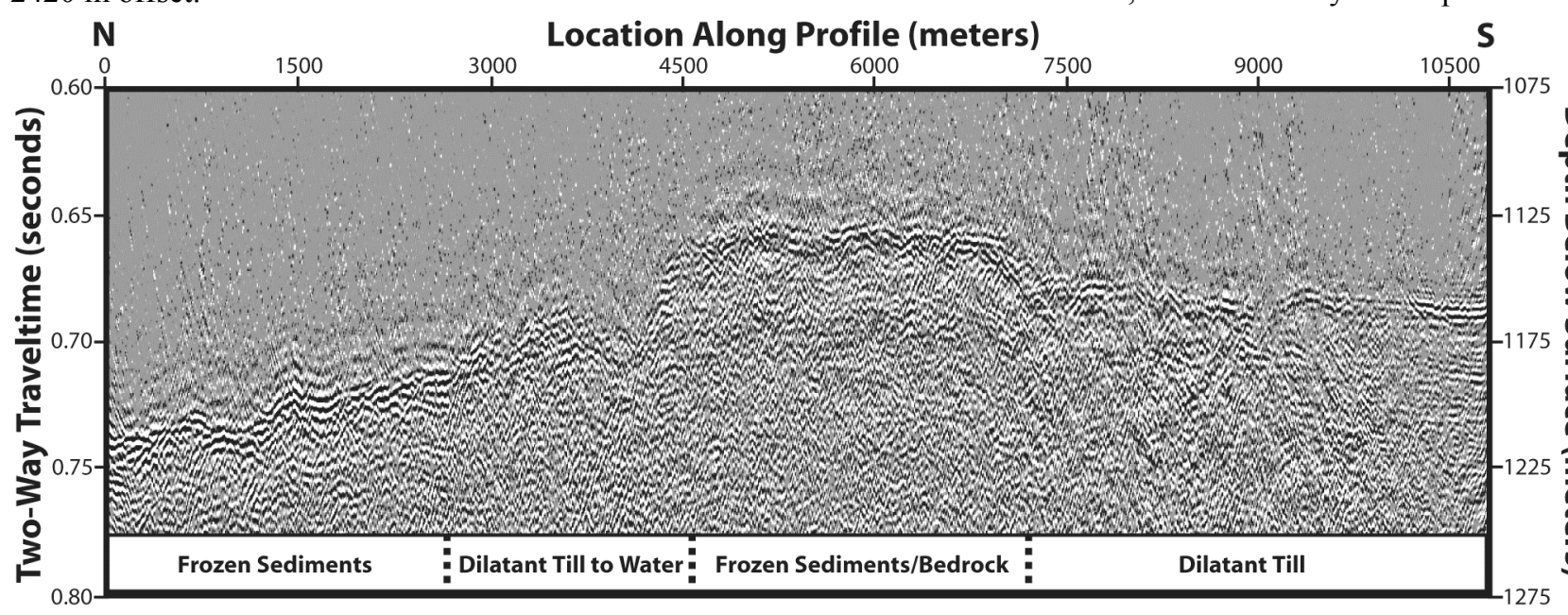

Figure 2. Processed seismic profile. This experiment imaged $10.8 \mathrm{~km}$ of the bed of Kamb Ice Stream, highlighting a local basal high and variable bed reflectivity. The profile is oriented transverse to ice flow, with flow coming out of the page at $\sim 20 \mathrm{~m} \mathrm{a}^{-1}$. The bright basal reflections $(0-2800 \mathrm{~m}, 4500-7300 \mathrm{~m})$ are indicative of frozen sediments. The weaker reflectors along the bed highlight soft sediments $(7300-10800 \mathrm{~m})$ and dilatant till to water $(2800-4500 \mathrm{~m})$. These basal observations are in agreement with recent radar studies performed near a pronounced sticky spot $\sim 30 \mathrm{~km}$ downstream of our study area (Catania et al., 2003; Jacobel et al., 2005; Pettersson et al., 2006).
Standard multi-channel seismic processing techniques were applied to generate the final seismic profile shown in Figure 2. Elevation statics were applied to account for variations in source depth and surface elevation along our seismic line. A high-pass filter was used to remove low frequency noise from the data, and FK filtering removed energy from surface arrivals, in addition to energy reverberations within the firn. A predictive deconvolution operator was employed to remove the ghost reflection observed in the data $\sim 20 \mathrm{msec}$ after the ice bottom reflection (A ghost reflection is the result of energy from a seismic source detonated at depth that first travels upward from the shot, reflects off the ice surface, and then travels downward through the ice.). Normal moveout corrections were made to flatten reflection hyperbolae and accurately place them according to subsurface structure. The data were also migrated to correctly position subsurface reflections, especially in the transition onto the subglacial high, where there is significant dip at the bed.

\section{AVO analysis}

The reflective strength of a seismic interface and its variation with source-receiver offset has formed the basis for seismic AVO analysis. Here the strength of a seismic reflection is used to determine the lithology and conditions along a seismic interface, given the overall reflection magnitude and phase. This is best summed up in the Zoeppritz equations, which model this seismic reflectivity as a function of source-receiver offset. The parameters needed by the Zoeppritz equations are the compressional wave (P-wave) velocity, shear wave (Swave) velocity, and density from both sides of the reflecting interface (Aki and Richards, 1980). A further assumption of a specular interface with semi-infinite layers is also made.

At normal incidence, the reflectivity is simplified to a 
function of the acoustic impedances (product of the Pwave velocity and density) of the two layers. Much work has been done to seismically constrain subglacial properties of the WAIS in this fashion (Robin, 1958; Bentley, 1971; Röthlisberger, 1972; Smith, 1997), as the strength of the bed in relation to the overlying ice can be determined from the phase and relative strength of the zero-offset reflection. However, this provides a nonunique solution for bed lithology, since no information on the shear strength of the bed is obtained. The S-wave velocity is vital in determining the presence of water, as water possesses no shear strength and lowers the S-wave velocity of a saturated or dilatant till considerably (Blankenship et al., 1986).

AVO analysis of the subglacial bed along our seismic profile has revealed variable basal conditions, ranging from a discontinuous dilatant till-water system to frozen sediments (Figure 2). Our reflection amplitude measurements came from common midpoint (CMP: different source-receiver offsets that reflect off the same portion of a seismic interface) gathers of the seismic data for incident angles that ranged from normal incidence to $\sim 42^{\circ}$, which were then inverted via the Zoeppritz equations to determine the seismic properties (and hence basal conditions) of the subglacial bed (Figure 3). Each CMP gather represents a $300 \mathrm{~m}$ segment of the bed, providing continuous coverage over our entire range of incidence angles.

\section{Discussion}

We observe three distinct reflective signatures from the bed of the ice along our profile (Figure 2): (1) frozen sediments, (2) weak, dilatant till, and (3) dilatant till to water. Frozen sediments exhibit a strong positive reflectivity that slightly weakens with increasing offset, revealing that the bed is quite competent in these regions (Figure 3A). These regions are observed both on the basal high, which appears to be at least partially covered with frozen sediments, and along the bed to the north of the basal high, where the bed consists primarily of frozen sediments (Figure 2). Dilatant till begins with a weak negative reflectivity at normal incidence that undergoes a phase reversal to positive reflectivity with increasing offset (Figure 3B). These conditions are largely observed on the south side of the basal high, show variations in their shear strength along the profile, and do not appear to possess enough continuity to maintain streaming ice conditions (Figure 2). Our observation of a dilatant tillwater system is made with only normal incidence data, as this occurs on north flank of the basal high where the dip at the bed is high and the effectiveness of AVO analysis at offset diminishes (Figure 2). Water at the bed gives a strong negative reflectivity at normal incidence, and the location of these observations along our profile lies within a hydropotential low. These variable wet bed - frozen bed conditions are in agreement with several radar studies performed further downstream along the trunk of Kamb
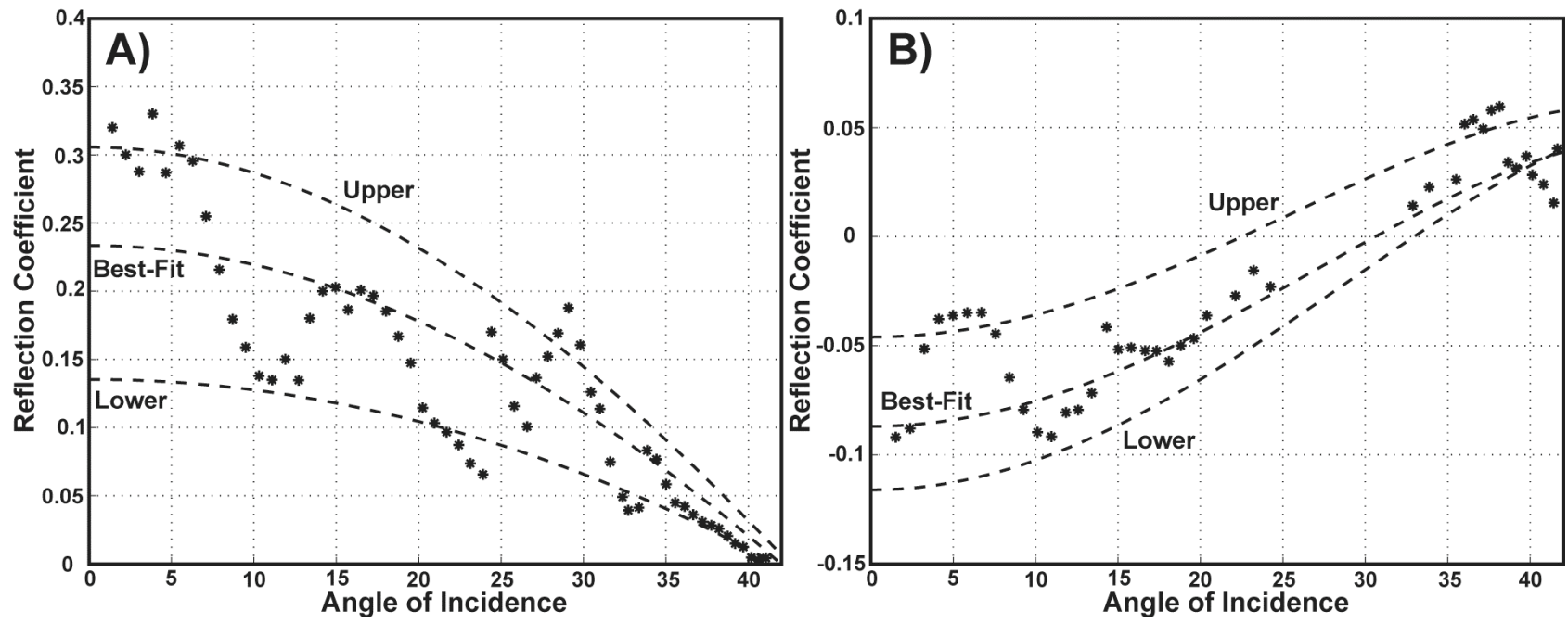

Figure 3. Reflectivity curves of two $300 \mathrm{~m}$ sections of the bed along the seismic profile. The stars are normalized seismic amplitude measurements, taken from normal incidence to $\sim 42^{\circ}$ angle of incidence. The dashed curves represent the best-fit seismic properties to the data (middle), as well as the upper and lower bounds to present how much the observed amplitude variability can influence the final seismic properties. The seismic properties that correspond to each dashed curve are listed in Table 1. A) AVO results for frozen till, taken from 900-1200 $\mathrm{m}$ along the seismic profile (Figure 2). B) AVO results for a dilatant till, taken from 9000-9300 $\mathrm{m}$ along the seismic profile (Figure 2). The data gap from $25-32^{\circ}$ angle of incidence is due to excessive ground noise damping the signal. The fluctuations in the data are due to weak 'waves' of ground noise distorting the true amplitudes in a few locations. Note the differences in vertical scale between Figures 3A and 3B to highlight the observed seismic reflectivities in each case. 
Table 1. Elastic properties derived from seismic AVO analysis of the ice-bed interface of Kamb Ice Stream

$\begin{array}{lccc}\text { Bed Lithology } & \text { S-wave Velocity }\left(\mathbf{m ~ s e c}^{-\mathbf{1}}\right) & \text { P-wave Velocity }\left(\mathbf{m ~ s e c} \mathbf{~ s}^{-\mathbf{1}}\right) & \text { Density }\left(\mathbf{k g ~ m}^{\mathbf{- 3}}\right) \\ \text { Ice } & 1850 & 3810 & 920 \\ \text { Frozen Sediments - Upper } & 2600 & 3700 & 1800 \\ \text { Frozen Sediments - Best Fit } & 2000 & 3000 & 1900 \\ \text { Frozen Sediments - Lower } & 1800 & 3100 & 1500 \\ \text { Dilatant Till - Upper } & 400 & 1700 & 1900 \\ \text { Dilatant Till - Best Fit } & 400 & 1750 & 1700 \\ \text { Dilatant Till - Lower } & 300 & 1650 & 1700\end{array}$

Note: The first lithology is that of ice, whose seismic properties were used in producing the curves shown in Figure 3. The following lithologies give the resultant seismic properties that correspond to the observed reflectivities of frozen sediments (Figure 3A) and dilatant till (Figure 3B).

Ice Stream (e.g., Jacobel et al., 1993; 2005; Retzlaff and Bentley, 1993; Bentley et al., 1998; Catania et al., 2003; Pettersson et al., 2006), suggesting that this discontinuity of a soft, deformable bed beneath the ice stream is linked to its ongoing stagnation. Continuity of soft, deformable sediments and the development of a subglacial water system beneath streaming ice are essential to maintain fast ice flow. This sediment-water system is present in many of the basal regions of the Siple Coast ice streams (e.g., Blankenship et al., 1986; 2001; Atre and Bentley, 1993; Bentley et al., 1998; Anandakrishnan, 2003; Catania et al., 2003; Peters et al., 2007), leading to fast ice flow along every Siple Coast ice stream except Kamb Ice Stream. A loss of basal water and the formation of sticky spots at the bed have been proposed as candidates for the ongoing shutdown of Kamb Ice Stream (e.g., Alley et al., 1994; Anandakrishnan et al., 2001). The seismic evidence presented here provides support for both hypotheses on the stagnation of Kamb Ice Stream.

The lack of sufficient basal water beneath the trunk of Kamb Ice Stream has led to alterations in till strength and basal lubrication. Zones of weak, dilatant till and water are interspersed with frozen sediments along our profile (Figure 2), increasing the roughness of an otherwise smooth bed. The soft, wet basal conditions are indicative of a basal water system present in the region, though their discontinuity suggests that subglacial water flow may be concentrated to a series of channels. Radar studies across a pronounced sticky spot $\sim 30 \mathrm{~km}$ downstream of our profile produced similar results, with wet basal conditions surrounding a rough high along the bed (Catania et al., 2003; Jacobel et al., 2005; Pettersson et al., 2006). We are unable to prove or disprove the existence of a distributed film of basal water along this region of Kamb Ice Stream, as a thin (cm-scale) layer of water cannot be seismically detected. However, this portion of the bed is actively freezing on (Joughin et al., 2003; Engelhardt, 2004), as we observe an extensive zone of frozen sediments along our profile. This process would eventually lead to increased focusing of the basal water system to channels, as well as increased strengthening of the surrounding till, to create a rougher bed that is more resistant to fast ice flow.
In addition, basal structure appears to have a strong influence on the current non-streaming conditions of Kamb Ice Stream. Along our profile, a prominent high in bedrock topography is present, rising as much as $200 \mathrm{~m}$ above the surrounding bed (Figure 2). This basal high acts as a major sticky spot, disrupting the continuity of the dilatant basal till layer and resisting fast ice flow. The bed also exhibits a rough topography where frozen sediments are present (Figure 2), further enhancing basal friction in the region.

The formation of sticky spots at the bed, either in the form of exposed bedrock or regions of frozen till, is supported by observations of high microseismicity along this portion of Kamb Ice Stream (Anandakrishnan and Alley, 1994). In the absence of a lubricating till layer, the ice encounters increased resistance as it flows over the rougher bed. Anandakrishnan and Alley (1994) observed increased microseismicity along the entire trunk of Kamb Ice Stream, reaching a maximum near our seismic profile, suggesting that regions in direct contact with bedrock or frozen till are regions of higher basal friction. Our transverse profile highlights several sticking points at the bed, revealing that portions of Kamb Ice Stream are resistant to fast ice flow, and that its subglacial water system may be channelized in this region (Kamb, 2001; Engelhardt, 2004), in agreement with the observed progression of ice stream stagnation along Kamb Ice Stream (Retzlaff and Bentley, 1993).

\section{Summary}

The ongoing shutdown of Kamb Ice Stream is the result of a disruption in continuous basal lubrication. Subglacial structure beneath a segment of the ice stream points to a basal high forming a major sticky spot, with a discontinuous drape of lubricating sediments and basal water beneath the ice stream. These variable basal conditions are in a region where the flow regime is in transition from fast ice flow to ice stream stagnation. Water is present at the bed to produce a dilatant till, though this basal water system appears to be discontinuous and may be experiencing basal freeze-on, as regions of frozen sediments are observed. These observations were made via seismic AVO analysis, which can be implemented as a powerful tool in constraining 
basal conditions beneath glaciated regions and obtaining a better understanding of the subglacial environment.

Acknowledgements. We thank Don Blankenship, Ginny Catania, Bob Jacobel, and Theresa Diehl for helpful reviews in improving the quality of this manuscript. We also thank the $2002-2003$ OND field party (A. Smith, D. Voigt, P Winberry, P. Braddock, R. Greschke, A. Morton, A. Mironov, S. O'Neel, M. Nolan), whose efforts were vital in acquiring the dataset presented. Funding for this study has been provided by the National Science Foundation (NSF OPP grants 00877507 and 0226535) and the Center for the Remote Sensing of Ice Sheets (CRESIS).

\section{References}

Aki, K., and P. G. Richards (1980), Quantitative Seismology - theory and methods, W. H. Freeman, San Francisco.

Alley, R. B., S. Anandakrishnan, C. R. Bentley, and N. Lord (1994), A water-piracy hypothesis for the stagnation of ice stream C, Antarctica, Ann. Glaciol., 20, 187-194.

Anandakrishnan, S., and R. B. Alley (1994), Ice stream C, West Antarctica, sticky spots detected by microearthquake monitoring, Ann. Glaciol., 20, 183-186.

Anandakrishnan, S., and R. B. Alley (1997), Stagnation of ice stream C, West Antarctica, by water piracy, J. Geophys. Res., 102, 1518315196.

Anandakrishnan, S., D. D. Blankenship, R. B. Alley, and P. L. Stoffa (1998), Influence of subglacial geology on the position of a West Antarctic ice stream from seismic observations, Nature, 394, 62-65.

Anandakrishnan, S., R. B. Alley, R. W. Jacobel, and H. Conway (2001), The flow regime of ice stream $\mathrm{C}$ and hypothesis concerning its recent stagnation, in The West Antarctic Ice Sheet: Behavior and Environment, Antarct. Res. Ser., vol. 77, edited by R. B. Alley and R. A. Bindschadler, AGU, pp. 283-294, Washington, D. C.

Anandakrishnan, S. (2003), Dilatant till layer near the onset of streaming ice flow of ice stream C, West Antarctica, determined by AVO (amplitude vs. offset) analysis, Ann. Glaciol., 36, 283-286.

Atre, S. R., and C. R. Bentley (1993), Laterally varying basal conditions beneath ice streams B and C, West Antarctica, J. Glaciol., 39, 507514.

Bell, R. E., D. D. Blankenship, C. A. Finn, D. L. Morse, T. A. Scambos, J. M. Brozena, and S. M. Hodge (1998), Influence of subglacial geology on the onset of a West Antarctic ice stream from aerogeophysical observations, Nature, 394, 58-62.

Bentley, C. R. (1971), Seismic evidence for moraine within the basal Antarctic Ice Sheet, in Antarctic Snow and Ice Studies II, Antarct. Res. Ser., vo. 16, edited by A. P. Crary, AGU, pp. 89-129, Washington, D. C.

Bentley, C. R., N. Lord, and C. Lui (1998), Radar reflections reveal a wet bed beneath stagnant ice stream $\mathrm{C}$ and a frozen bed beneath ridge BC, West Antarctica, J. Glaciol., 44 (246), 149-156.

Bindschadler, R., P. Vornberger, and L. Gray (2005), Changes in the ice plain of Whillans Ice Stream, West Antarctica, J. Glaciol., 51 (175), 620-636.

Blankenship, D. D., C. R. Bentley, S. T. Rooney, and R. B. Alley (1986), Seismic measurements reveal a saturated porous layer beneath an active Antarctic ice stream, Nature, 322, 54-57.

Blankenship, D. D., D. L. Morse, C. A. Finn, R. E. Bell, M. A. Peters, S. D. Kempf, S. M. Hodge, M. Studinger, J. C. Behrendt, and J. M. Brozena (2001), Geologic controls on the initiation of rapid basal motion for West Antarctic ice streams: A geophysical perspective including new airborne radar sounding and laser altimetry results, in The West Antarctic Ice Sheet: Behavior and Environment, Antarct. Res. Ser., vol. 77, edited by R. B. Alley and R. A. Bindschadler, AGU, pp. 105-121, Washington, D. C.

Catania, G. A., H. B. Conway, A. M. Gades, C. F. Raymond, and H. Engelhardt (2003), Bed reflectivity beneath inactive ice streams in West Antarctica, Ann. Glaciol., 36, 287-291.

Conway, H., G. Catania, C. F. Raymond, A. M. Gades, T. A. Scambos, and H. Engelhardt (2002), Switch of flow direction in an Antarctic ice stream, Nature, 491 (6906), 465-467.

Engelhardt, H. (2004), Thermal regime and dynamics of the West Antarctic Ice Sheet, Ann. Glaciol., 39, 85-92.
Haran, T., J. Bohlander, T. Scambos, and M. Fahnestock (2005), MODIS Mosaic of Antarctica image map, National Snow and Ice Data Center, Boulder, CO, digital media.

Jacobel, R. W., T. A. Gades, D. L. Gottschling, S. M. Hodge, and D. L. Wright (1993), Interpretation of radar-detected internal layer folding in West Antarctic ice streams, J. Glaciol., 39 (133), 528-537.

Jacobel, R. W., T. A. Scambos, C. R. Raymond, and T. A. Gades (1996), Changes in the configuration of the ice stream flow from the West Antarctic Ice Sheet, J. Geophys. Res., 101 (B3), 5499-5504.

Jacobel, R. W., T. A. Scambos, N. A. Nereson, and C. F. Raymond (2000), Changes in the margin of ice stream C, Antarctica, J. Glaciol., 46 (152), $102-110$.

Jacobel, R. W. R. Pettersson, D. Osterhouse, S. Tulaczyk, and I. Howat (2005), Radar studies of the trunk and 'sticky spot' of Kamb Ice Stream, Eos Trans. AUG, 85 (52), Fall Meet. Suppl., Abstract C51A0262.

Joughin, I., S. Tulaczyk, and H. Engelhardt (2003), Basal melt beneath Whillans Ice Stream and ice streams A and C, West Antarctica, Ann. Glaciol., 36, 257-262.

Joughin, I., R. A. Bindschadler, M. King, D. Voigt, S. Anandakrishnan, R. Alley, L. Peters, H. Horgan, P. Winberry, S. Das, and G. Catania (2005), Continued deceleration of Whillans Ice Stream, West Antarctica, Geophys. Res. Lett., 32, doi: 10.1029/2005GL02431.

Kamb, B. (2001), Basal zone of the West Antarctic ice streams and its role in lubrication of their rapid motion, in The West Antarctic Ice Sheet: Behavior and Environment, Antarct. Res. Ser., vol. 77, edited by R. B. Alley and R. A. Bindschadler, AGU, pp. 157-199, Washington, D. C.

Oppenheimer, M. (1998), Global warming and the stability of the West Antarctic Ice Sheet, Nature, 393, 325-332.

Peters, L. E., S. Anandakrishnan, R. B. Alley, J. P. Winberry, D. E. Voigt, A. M. Smith, and D. L. Morse (2006), Subglacial sediments as a control on the onset and location of two Siple Coast ice streams, West Antarctica, J. Geophys. Res., 111, B01302, doi: 10.1029/2005JB03766.

Peters, L. E., S. Anandakrishnan, R. B. Alley, and A. M. Smith (2007), Extensive storage of basal meltwater near the onset of a major West Antarctic ice stream, Geology, 35 (3), 251-254, doi: 10.1130/G23222A.

Pettersson, R., R. W. Jacobel, D. Osterhouse, S. Tulaczyk, and I. Howat (2006), Radar studies of the lower trunk of Kamb Ice Stream, Geophysical Research Abstracts, 8 (02968), sRef-ID: 16077962/gra/EGU06-A-02968.

Retzlaff, R., and C. R. Bentley (1993), Timing and stagnation of ice stream C, West Antarctica, from short-pulse radar studies of buried surface crevasses, J. Glaciol., 39 (133), 553-561.

Robin, G. de Q. (1958), Glaciology III, Seismic shooting and related investigations, Norw. Brit. Swed. Antarct. Exped., 1949-51, vol. 5, Norsk Polarinstitutt, Oslo, Norway.

Röthlisberger, H. (1972), Seismic exploration in cold regions, CRREL Monogr. II-A 2a, Cold Reg. Res. and Eng. Lab., Hanover, N. H.

Scherer, R. P., A. Aldahan, S. Tulaczyk, G. Possnert, H. Engelhardt, and B. Kamb (1998), Pleistocene collapse of the West Antarctic Ice Sheet, Science, 281, 82-85.

Smith, A. M. (1997), Basal conditions on Rutford Ice Stream, Antarctica, from seismic observations, J. Geophys. Res., 102, 543552.

Studinger, M., R. E. Bell, D. D. Blankenship, C. A. Finn, R. A. Arko, D. L. Morse, and I. Joughin (2001), Subglacial sediments: A regional geological template for ice flow in West Antarctica, Geophys. Res. Lett., 28 (18), 3493-3496. 